Sains Malaysiana 49(8)(2020): 1875-1890

http://dx.doi.org/10.17576/jsm-2020-4908-10

\title{
Opto-Electrical Investigation of Zn Metal-Doped Cds and Their Application in Soft Lithographic Technique
}

(Kajian Opto-Elektrik ke atas Zn Logam-terdop Cd dan Aplikasinya dalam Teknik Litografi Lembut)

\author{
Gulalai Hussain, Uzma JabeEn*, Irfan Hafeez, M Najam Khan Malghani, Ayesha MushtaQ*, SabeEnA \\ RizWAN, FARruKh BASHIR, FARIDA BEHLIL, M AAMIR RAZA \& SHAISTA ANJUM
}

\begin{abstract}
Un-doped CdS and Zn metal-doped CdS (0.1-0.5 M) were synthesized by chemical precipitation method. Properties like optical band gap and conductivity were determined by different characterization techniques. UV-Visible spectroscopy was applied to estimate the band gap where it showed a significant blue shift due to quantum confinement effect. Size determined by scanning electron microscopy (SEM) was found to be in nanorange from 41 to $60 \mathrm{~nm}$ for both un-doped and metal doped CdS nanocrystals. EDAX confirmed the doping by showing peak for Zn. XRD (X-ray diffraction) showed the lattice structure to be cubic for the synthesized nanoparticles and conductivity for un-doped

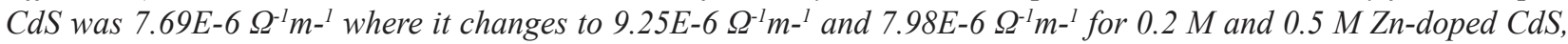
respectively. In order to obtain good results, nanocrystals having highest conductivity are used in soft lithographic technique. Here $\mu T M$ (micro transfer-molding) was followed for patterning with PDMS (poly-(dimethylsiloxane)) mold and silicon substrate for better results.
\end{abstract}

Keywords: Band gap; blue shift; conductivity; lithography; Zn dopant

ABSTRAK

CdS yang tidak terdop dan Zn logam-terdop (0.1-0.5M) disintesis dengan kaedah pemendakan kimia. Sifat seperti jurang jalur optik dan kekonduksian ditentukan oleh teknik pencirian yang berbeza. Spektroskopi Terlihat UV diterapkan untuk menganggarkan jurang jalur yang menunjukkan peralihan warna biru yang ketara kerana kesan pengurungan kuantum. Ukuran yang ditentukan oleh mikroskopi elektron pengimbasan (SEM) didapati berada dalam jarak nano dari 41 hingga $60 \mathrm{~nm}$ untuk kristal nano CdS yang tidak dilekatkan dan logam. EDAX mengesahkan pendopan dengan menunjukkan puncak untuk Zn. XRD (difraksi sinar-X) menunjukkan struktur kisi menjadi kubik bagi zarah nanopartesis yang disintesis dan kekonduksian untuk CdS tanpa pendopan adalah $7.69 E-6 \Omega^{-1} m^{-1}$ dan ia berubah menjadi 9.25E-6 $\Omega^{-1} m^{-1}$ dan 7.98E-6 $\Omega^{-1} m^{-1}$ masing-masing untuk 0.2 M dan 0.5 M Zn-terdop CdS. Untuk memperoleh hasil yang baik, kristal nano yang mempunyai kekonduksian tertinggi digunakan dalam teknik litografi lembut. Di sini $\mu$ TM (acuan pemindahan mikro) dilakukan untuk membuat corak dengan substrat acuan dan silikon PDMS (poli- (dimetilsiloksana)) untuk hasil yang lebih baik.

Kata kunci: Jurang jalur; kekonduksian; litografi; peralihan biru; Zn dopan

\section{INTRODUCTION}

Cadmium sulfide is a very prominent semiconductor material which is widely applicable in various fields such as thin film solar cell due to its unique optical and electrical properties (Kazmerski 2006; Wu 2004). These nanoparticles with such dynamic properties are due to certain characters such as its shape and size in addition to quantum confinement effect (Brus 1984).

Inserting a foreign element into the main lattice structure like a transition metal reported new properties into the host material by substituting itself with the mother element. These changes include band gap tuning and conductivity changes which are further more applicable in photocatalysis (Erwin et al. 2005).

Apart from $\mathrm{Zn}$ other impurity such as $\mathrm{Cu}, \mathrm{Co}$, and $\mathrm{Hg}$ are considered as a promising candidate for band gap tuning and can be used in various fields (Huse et al. 2013). Ni, Co, Ce and Sb doped CdS has increased band gap which enhanced its photocatalytic behavior and hence were proven to have better degradation efficiency (Irem \& Boz 2017). Cu-doped CdS synthesized by chemical spray pyrolysis method showed a decrease in the electrical conductivity in the initial stage but increased with increasing doping concentration. In addition, $\mathrm{CdS}$ thin film doped with $\mathrm{Ga}$ and $\mathrm{Zn}$ showed to 
be very beneficial in solar cell, sensor and other electronic devices (Jabeen et al. 2016).

Lithography has its implementation in different fields as worked with soft lithography in micro reactors to screen the protein crystallization. Photolithography is a process used in microfabrication involving light to remove the thin film parts (Xia \& Whitesides 1998).

Soft lithographic techniques are bundle of techniques applied patterning and fabrication. Other techniques are nano imprint lithography and photolithography. Soft lithography is more convenient due to some reasons which includes low costs and easy handling. It can produce patterning from nano scale to micro scale level and follow self-assembly approach (Khan et al. 2009). Polymer poly (4- styrene sulfonate) doped with (3, 4 ethylenedioxythiophene) was patterned on silicon or glass substrate by micro molding technique to obtain nanowires by varying the force applied on the pattern different properties were influenced such as height and surface structure. These materials found its application in opto-electronic devices (Zheng et al. 2003). Three soft lithographic techniques such as laminar flow patterning, micro-contact printing and patterning using microfluidic channels were used for the patterning of proteins and cell, where different applications were seen for the control of cellular content and surface chemistry, and could be applicable in tissue engineering and biosensor technology (Kane et al. 1999).

The main objective of this study was to synthesized pure and $\mathrm{Zn}$-doped CdS nanocrystal and characterized them by different technique. To see the effect of doping concentration on the optical and electrical parameters as well as the influence on the lithographical application.

\section{MATERIALS AND METHODS}

\section{CHEMICALS}

Cadmium acetate $\left.\left(\mathrm{CH}_{3} \mathrm{COO}\right)_{2} \mathrm{Cd} .2 \mathrm{H}_{2} \mathrm{O}\right)$, Sodium sulfide $\left(\mathrm{Na}_{2} \mathrm{~S}\right)$ and Zinc acetate $\left(\mathrm{Zn}\left(\mathrm{CH}_{3} \mathrm{COO}\right)_{2}\right.$ of analytical grade were purchased from Merck. Distilled water and absolute alcohol were used as solvents. All the chemicals were used without further purification.

\section{SYNTHESIS OF UN-DOPED CDS}

Chemical precipitation method was applied for the synthesis of CdS nanoparticles (Murugadoss 2012). 1 M solution of $\mathrm{Cd}$ acetate $\left(\mathrm{CH}_{3} \mathrm{COO}\right)_{2} \mathrm{Cd} .2 \mathrm{H}_{2} \mathrm{O}$ and sodium sulfide $\left(\mathrm{Na}_{2} \mathrm{~S}\right)$ were prepared in 1:1 solvent of distilled water and ethanol. Solutions were prepared in $30 \mathrm{~mL}$ of solvent; $\mathrm{Cd}$ acetate solution was put on stirring machine at $60{ }^{\circ} \mathrm{C}$ whereas $\mathrm{Na}_{2} \mathrm{~S}$ was added drop wise into the solution where it turns into yellowish orange color. After $1 \mathrm{~h}$ of stirring a homogeneous solution of CdS was obtained which was washed with the distilled water and ethanol several times. The precipitates were dry in oven at $120^{\circ} \mathrm{C}$ and used for further characterization.

\section{SYNTHESIS OF ZN-DOPED CDS}

$1 \mathrm{M}$ solution of both sodium sulfide and cadmium acetate were prepared in $30 \mathrm{~mL}$ of distilled waterethanol of $50 / 50$ by volume for the synthesis of $\mathrm{Zn}$ doped CdS nanomaterial. Next, different concentrations of zinc acetate solution (0.1-0.5 M) were mixed with cadmium acetate solution under constant stirring at 60 ${ }^{\circ} \mathrm{C}$ for 20 min. Afterwards, sodium sulfide was added drop wise to the above reaction mixture under constant stirring for $30 \mathrm{~min}$ and color turned from transparent to yellow color. The precipitate obtained were established at room temperature to stop the reaction. Washing was followed with same solvent to separate out the remaining reactants. Finally, metal doped $\mathrm{CdS}$ nanocrystals were dried in oven at $120^{\circ} \mathrm{C}$ for $2 \mathrm{~h}$ and subjected to different characterization techniques.

\section{PDMS MOLD AND SUBSTRATE PREPARATION}

The modal material consisting of curing agent and monomer were Poly-(dimethylsiloxane) PDMS Sylguard 184 kit (Dow Corning Corporation, Michigan, United States). Following the standard procedure, the ratio of 10:1 of monomer and curing agent were mixed. The mixture was put in vacuum where string led to the evolution of air bubble. The vacuum was adjusted and mixture was put in the desiccator. After $30 \mathrm{~min}$ of degassing with close lid air bubbles were removed.

Afterwards, at the temperature of $40{ }^{\circ} \mathrm{C}$ a silicon master with line width of $2 \mu \mathrm{m}$ was mounted over a hot plate. The PDMS was poured onto this silicon mater after a Teflon ring has been put over the patterned area. While pouring the PDMS on the plate, some air bubbles rose up from it as they float to the upper area during the pouring of liquid pre-polymer. The mixture was left to settle for 5-6 h. The completion of curing result in the negative pattern of master in the mold which was further peeled off and cut into $1.5 \times 1.5 \mathrm{~cm}^{2}$ pieces with diamond cutter and blown with jet of $\mathrm{CO}_{2}$ crystals.

\section{RESULTS AND DISCUSSION}

\section{UV-VISIBLE ANALYSIS AND BAND GAP TUNING}

Figure 1 depicts the UV-Visible data for un-doped and $\mathrm{Zn}$-doped $\mathrm{CdS}$ with the doping concentration ranging from 0.1 to $0.5 \mathrm{M}$. The un-doped CdS has the maximum absorption edge at $489 \mathrm{~nm}$ however by the incorporation of $\mathrm{Zn}$ atoms in the lattice spaces of $\mathrm{CdS}$, the absorption wavelength shifts towards the lower wavelength region. Wavelength of the $\mathrm{Zn}$ incriminated CdS having $\mathrm{Zn}$ contents from 0.1 to $0.5 \mathrm{M}$ are $483,477,473,441$, and $433 \mathrm{~nm}$, respectively, which confirms the quantum confinement effect. 

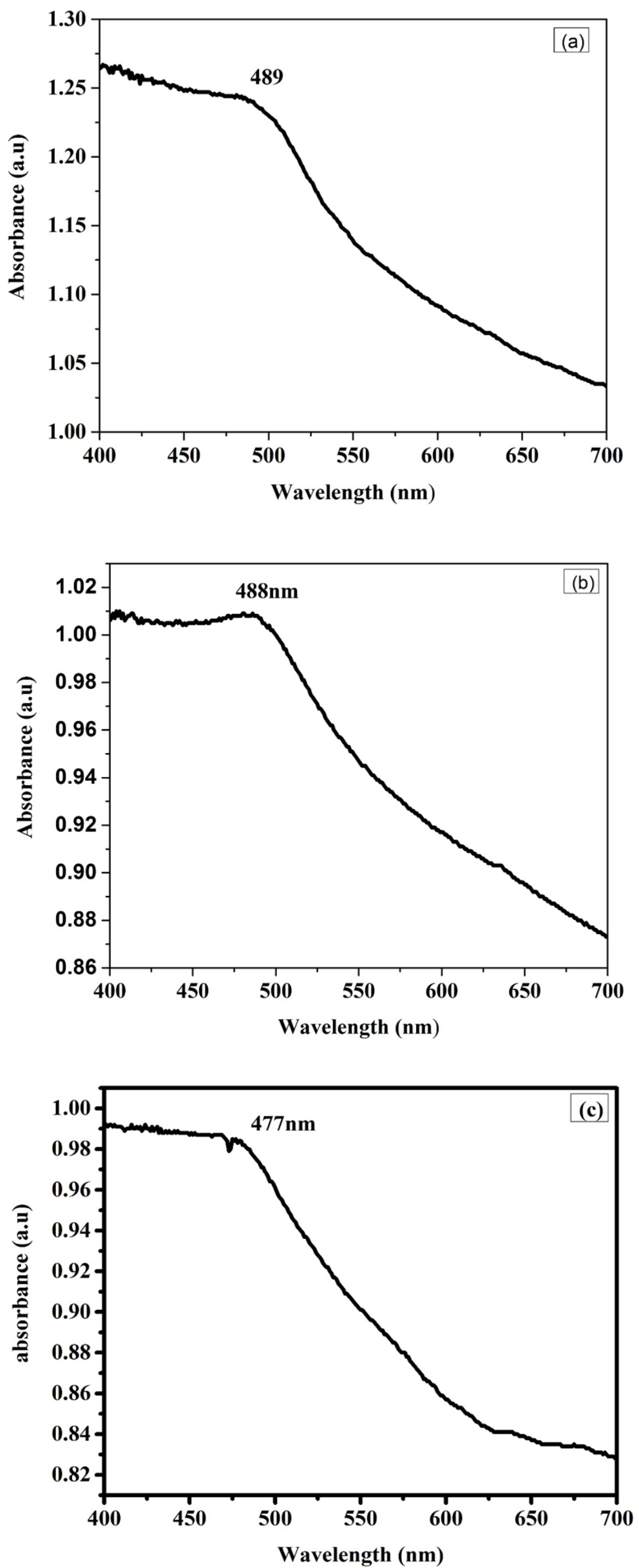

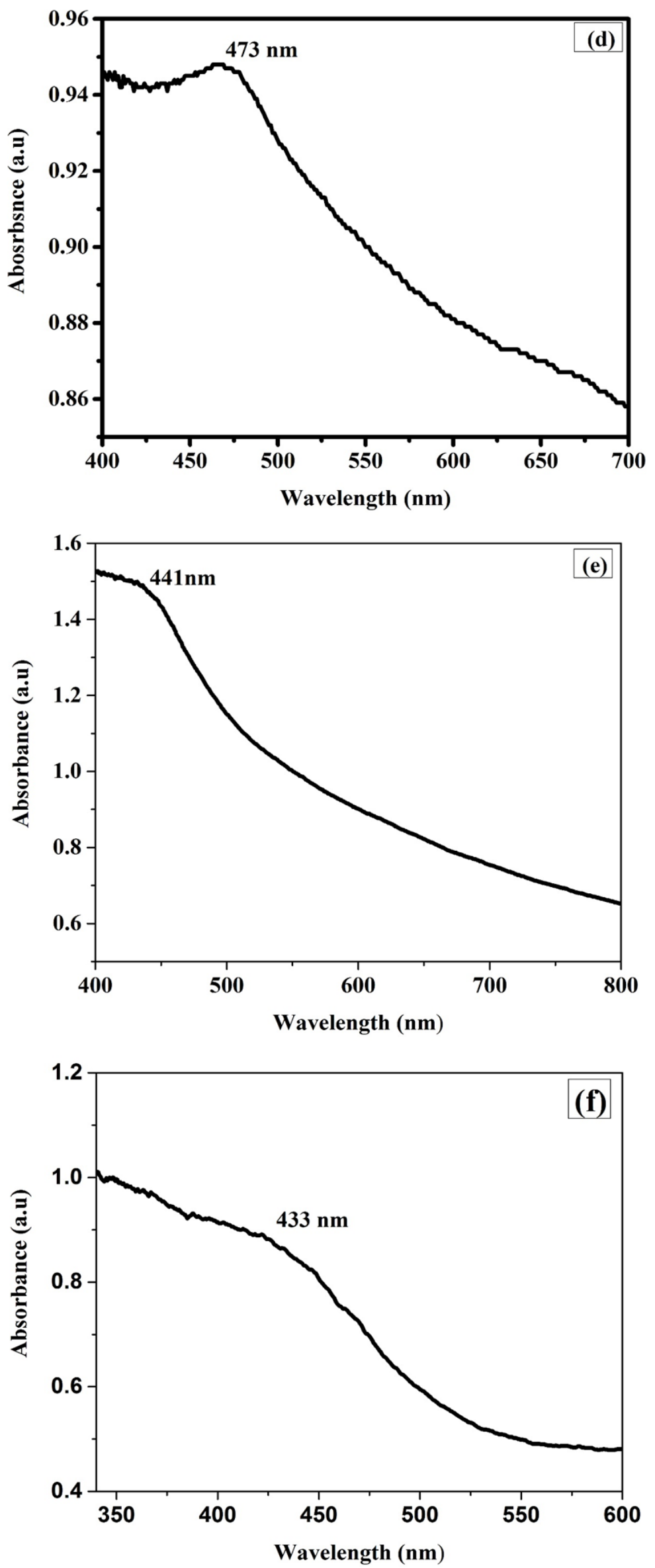

FIGURE 1. UV-visible spectra of (a) un-doped CdS, (b) $0.1 \mathrm{M}$ Zn-doped CdS, (c) $0.2 \mathrm{M} \mathrm{Zn-}$ doped CdS, (d) 0.3 M Zn-doped CdS, (e) 0.4 M Zn-doped CdS, (f) 0.5 M Zn-doped CdS 
Band gap is a vital property of nanocrystals which is determined by plotting graph between $(\alpha h v)^{2}$ versus $(h v)$ termed as Tauc plot. It is noted that $\mathrm{Eg}$ of the un-doped $\mathrm{CdS}$ nanocrystals is $2.35 \mathrm{eV}$ (Figure 2). However, after the increment of $\mathrm{Zn}$ impurity in CdS lattice, band gap was tuned to $1.96,1.99,2.11,2.19$, and $2.21 \mathrm{eV}$ for 0.1 to 0.5 M impurity, respectively, shown in Table 1. It is noted that with the increase in the concentration of dopant material, the absorption band shifts towards the lower wavelength due to quantum confinement effect.
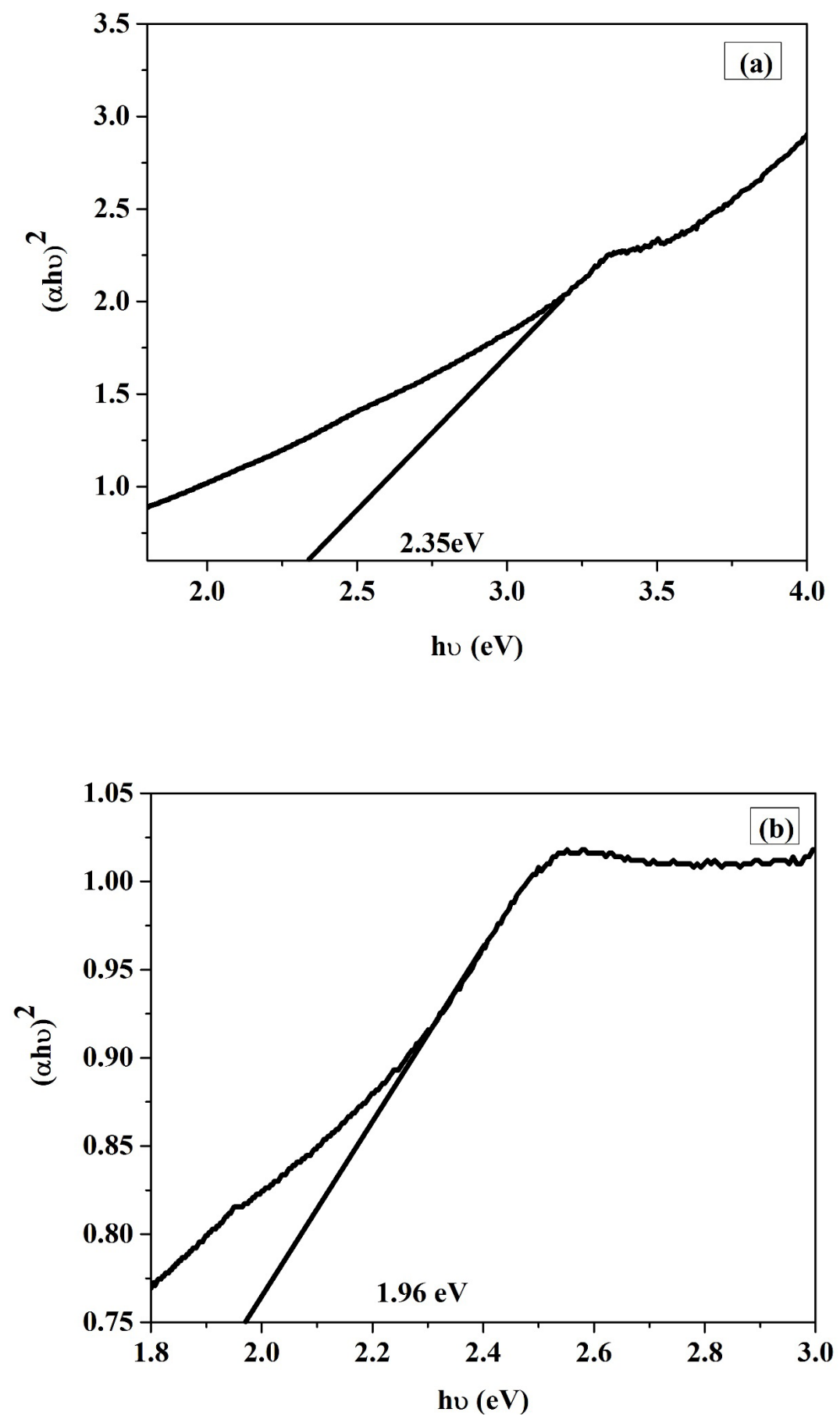

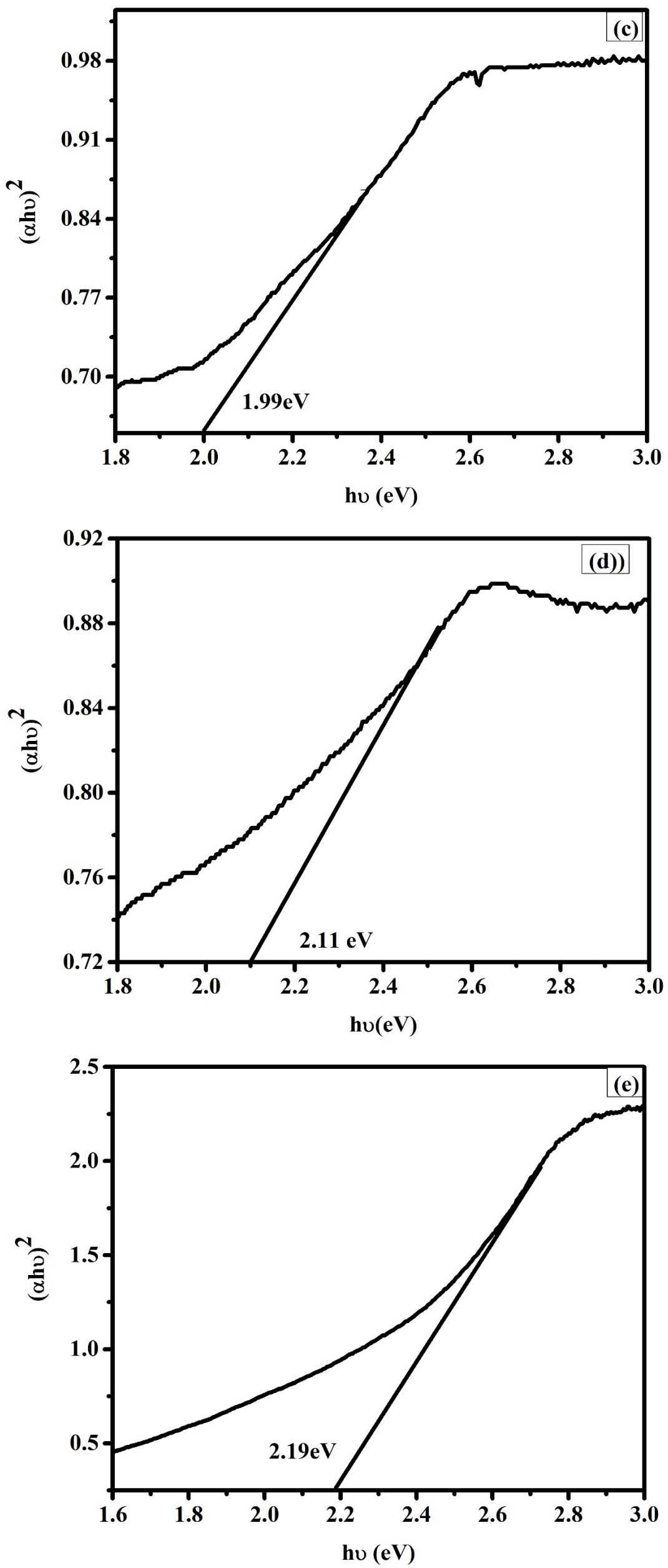


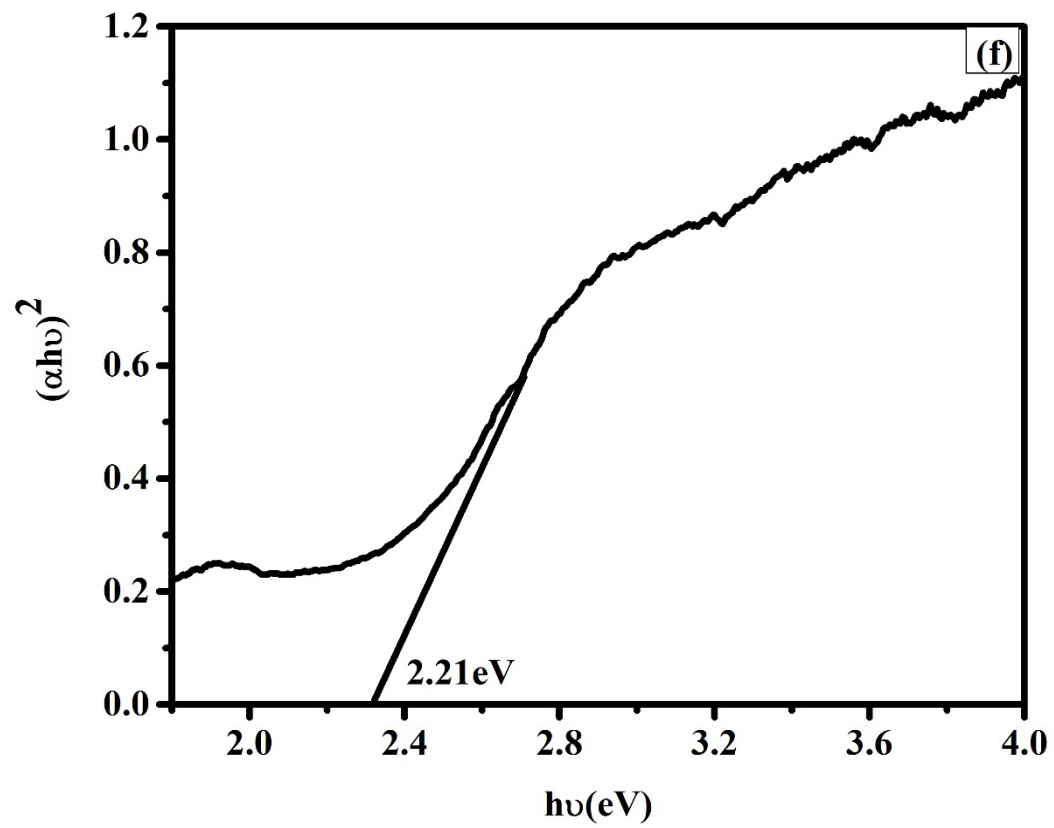

FIGURE 2. Tauc plot for (a) un-doped CdS, (b) $0.1 \mathrm{M} \mathrm{Zn-doped} \mathrm{CdS,} \mathrm{(c)} 0.2 \mathrm{M} Z$ Zn-doped CdS, (d) 0.3 M Zn-doped CdS, (e) 0.4 M Zn-doped CdS, and (f) $0.5 \mathrm{M}$ Zn-doped CdS

TABLE 1. Absorption edge, and band gap of un-doped and Zn-doped CdS

\begin{tabular}{lccc}
\hline \multicolumn{1}{c}{ Sample } & Absorption edge $(\mathrm{nm})$ & Band gap $(\mathrm{eV})$ & $\begin{array}{c}\text { Decrease with respect to } \\
\text { CdS }\end{array}$ \\
\hline $\mathrm{CdS}$ & 489 & 2.34 & - \\
$0.1 \mathrm{M}$ Zn-doped CdS & 488 & 1.96 & 0.38 \\
$0.2 \mathrm{M}$ Zn-doped CdS & 477 & 1.99 & 0.35 \\
$0.3 \mathrm{M}$ Zn-doped CdS & 473 & 2.11 & 0.15 \\
$0.4 \mathrm{M} Z$ Zn-doped CdS & 441 & 2.19 & 0.13 \\
$0.5 \mathrm{M} Z$ Zn-doped CdS & 433 & 2.21 & \\
\hline
\end{tabular}

\section{FTIR INTERPRETATION}

Figure 3 displays the FTIR spectra of un-doped and Zndoped CdS nanocrystals in the range of 500 to $4000 \mathrm{~cm}^{-1}$. FTIR spectra confirmed purity and composition of the semiconductor nanocrystals. Various peaks attained from the synthesized sample could be explained by FTIR. The absorption peak attained in the range from 3600 to 3100 $\mathrm{cm}^{-1}$ corresponds to the hydroxyl group of $\mathrm{H}_{2} \mathrm{O}$ molecule adsorbed by the synthesized samples. Metal-sulfur bond exhibits band the range of 530 to $600 \mathrm{~cm}^{-1}$. However, some additional peaks are present in range from 634 to $638 \mathrm{~cm}^{-1}$ which are due to $\mathrm{Zn}-\mathrm{S}$ bond, indicating the successful doping of zinc metal in CdS lattice (Jabeen et al. 2016). 

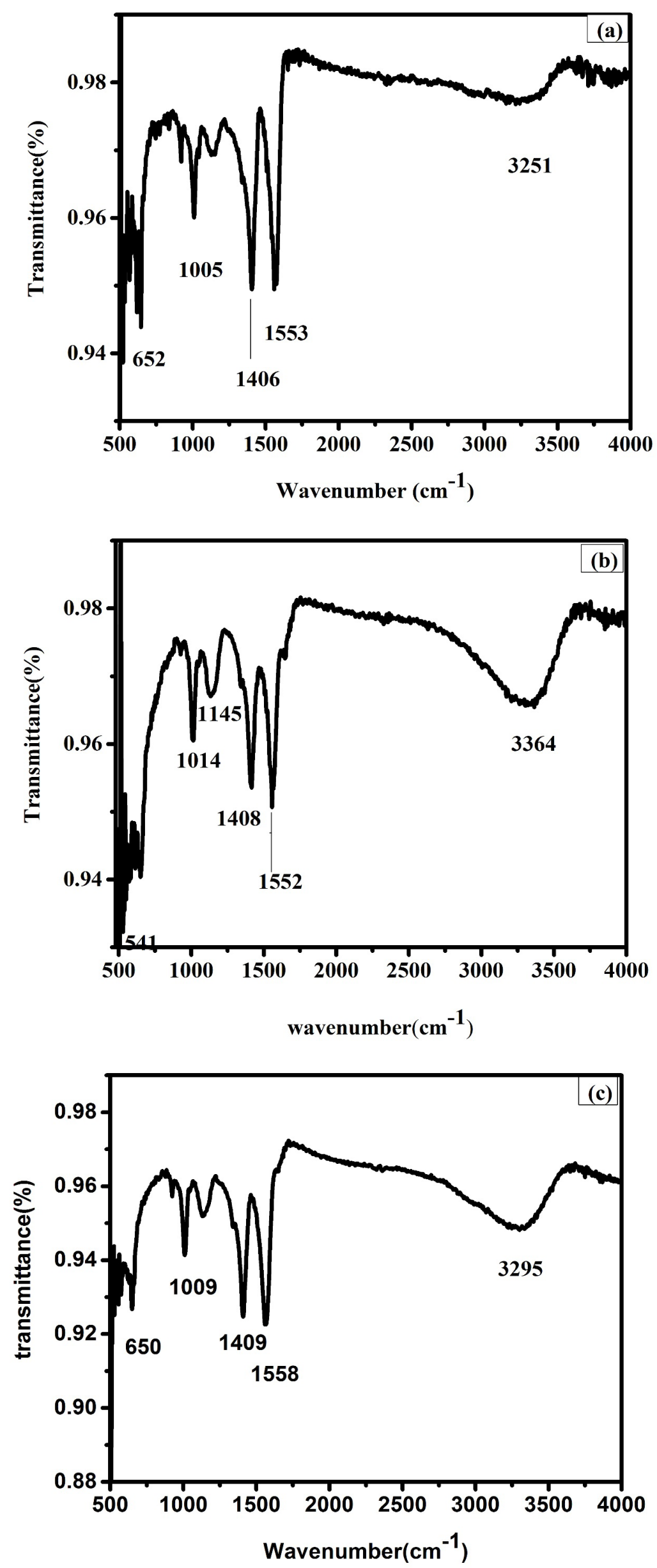

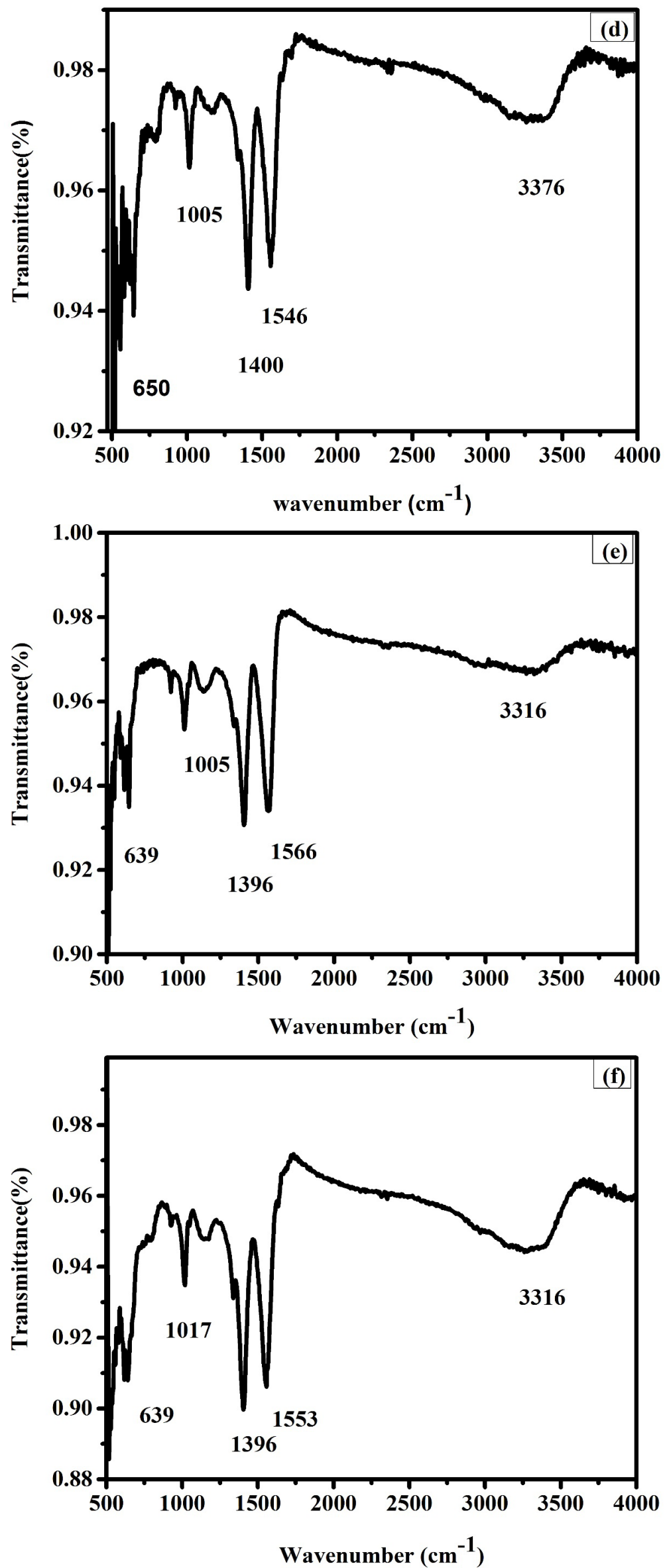

FIGURE 3. FTIR spectra of (a) un-doped CdS, (b) $0.1 \mathrm{M}$, Zn-doped CdS, (c) $0.2 \mathrm{M}$, Zn-doped CdS, (d) 0.3 M, Zn-doped CdS, (e) 0.4 M, Zn-doped CdS, (f) 0.5 M, Zn-doped CdS 
X-RAY MEASUREMENT

$\mathrm{X}$-ray analysis in nanotechnology is applied for the determination of particles size and crystal structure. X-ray diffraction pattern for un-doped CdS and Zn-doped CdS nanocrystals $(0.2$ and $0.4 \mathrm{M})$ displayed in Figure 4 with reference 42-1411 from JCPDS-2002 for cubic structure. Angles are located at $26.62,43.89$, and $51.44^{\circ}$ which corresponds to the miller indices of (111), (220), and
(311), respectively. Apart from the three-characteristic peaks for cubic structure, no extra peaks were observed in doped material giving an indication of successful doping where $\mathrm{Zn}$ atom substitute $\mathrm{Cd}$ in lattice structure due to comparability of ionic radius between $\mathrm{Zn}$ and $\mathrm{Cd}$. The intensity of peaks for un-doped CdS is higher than doped particles but it increases from 0.2 to $0.4 \mathrm{M}$ doped crystal.
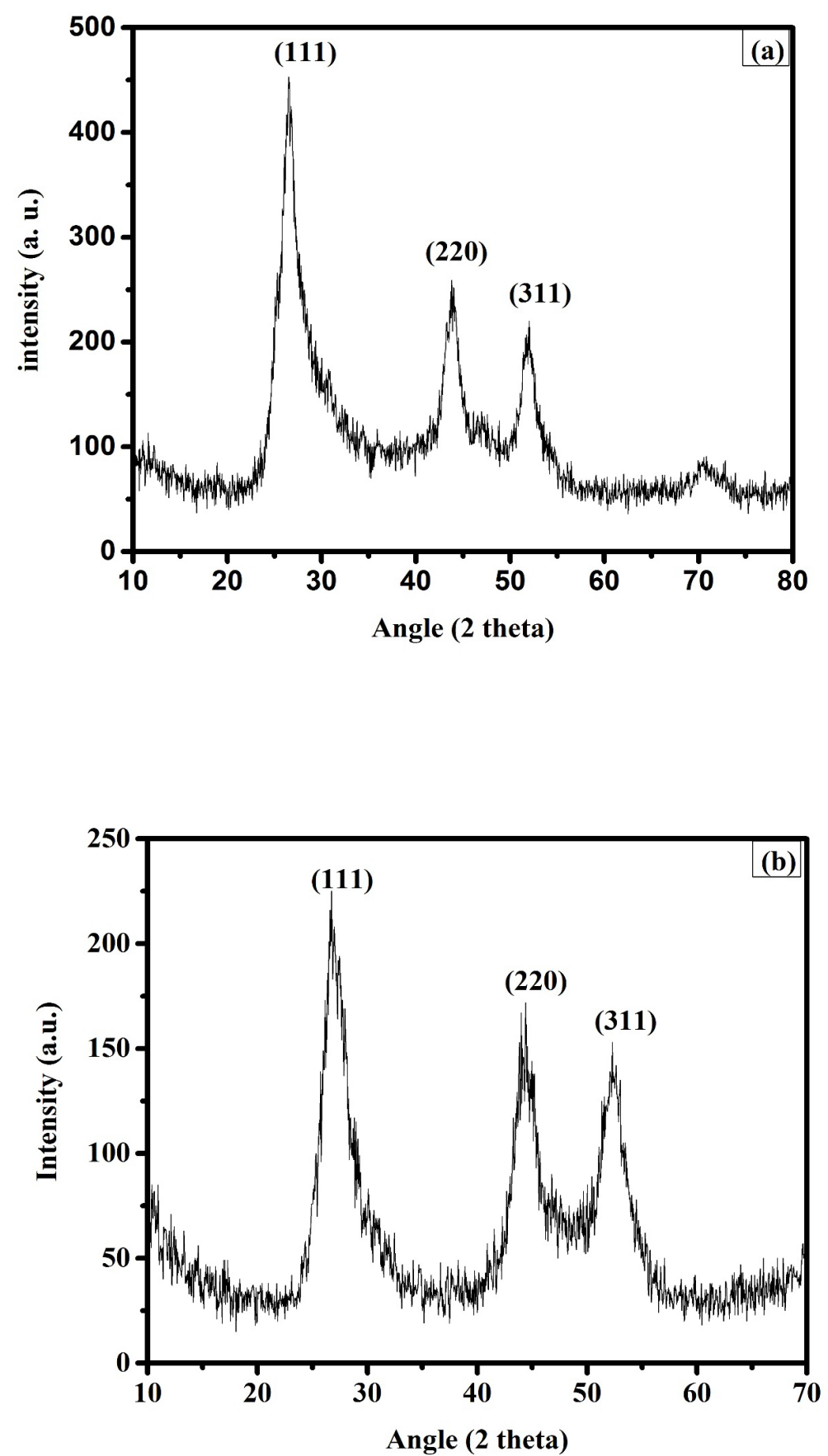


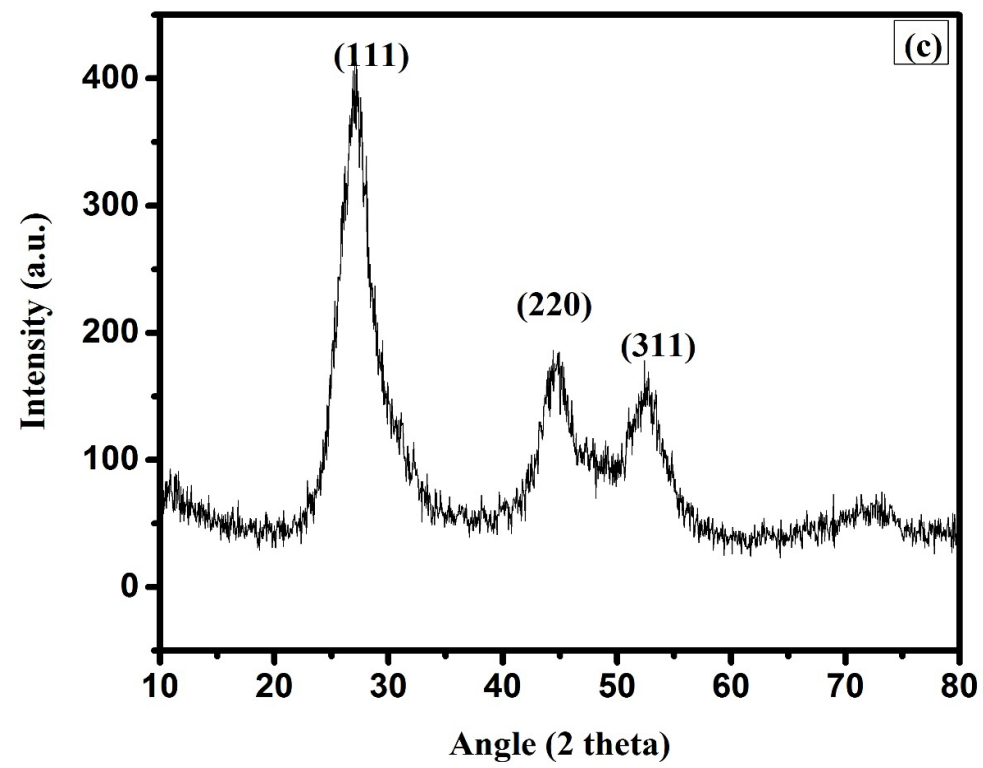

FIGURE 4. XRD pattern of (a) un-doped CdS, (b) Zn-doped CdS (0.2 M) and (c) Zndoped CdS (0.4 M) nanocrystals

\section{ELEMENTAL ANALYSIS BY EDAX}

EDAX was carried out to explore the elemental composition of un-doped and Zn-doped $\mathrm{CdS}$ nanoparticles. EDAX spectra depicted in Figure 5 which indicate the presence of elements $\mathrm{Cd}, \mathrm{S}$, and $\mathrm{Na}$ by their peaks in un-doped nanoparticle. $\mathrm{Cd}$ and $\mathrm{S}$ are the parent elements of the lattice, but $\mathrm{Na}$ peaks is due to the sodium sulfide precursor used in synthesis procedure. $\mathrm{Cd}: \mathrm{S}$ average atomic percentage ratio is $47.50: 42.92$ whereas the composition (mass\%) is $76.98: 19.84$ for $\mathrm{Cd}$ and $\mathrm{S}$, respectively, earning the confirmation of $\mathrm{CdS}$ production.
On the other hand, in doped material, an extra peak regarding $\mathrm{Zn}$ in observed with doping molarity of 0.3 , and $0.4 \mathrm{M}$. Composition (mass $\%$ ) for 0.3 and $0.4 \mathrm{M}$ were determined to be 26.64:10.67:2.61 and 51.03:18.35:7.10, respectively, which was the evidence of successful doping of metal in cadmium sulfide nanocrystals. Table 2 gives the compositions of synthesized sample of undoped CdS, doped CdS (Zn 0.3 M) and doped CdS (Zn $0.4 \mathrm{M}$ ) nanocrystals, respectively, in atomic and mass percentages.

TABLE 2. Showing the composition of (a) CdS, (b) $0.3 \mathrm{M} \mathrm{Zn} \mathrm{doped} \mathrm{CdS,} \mathrm{(c)} \mathrm{and} 0.4 \mathrm{M}$ Zn doped CdS

a

\begin{tabular}{|c|c|c|}
\hline Element & Mass $\%$ & Atomic $\%$ \\
\hline $\mathrm{Na}$ & 3.18 & 9.95 \\
\hline S & 19.94 & 42.92 \\
\hline $\mathrm{Cd}$ & 76.98 & 47.50 \\
\hline Total & 100 & 100.37 \\
\hline
\end{tabular}




\begin{tabular}{|c|c|c|}
\hline \multicolumn{3}{|c|}{$\mathrm{b}$} \\
\hline Element & Mass $\%$ & Atomic $\%$ \\
\hline $\mathrm{O}$ & 34.39 & 55.44 \\
\hline $\mathrm{Na}$ & 25.70 & 28.83 \\
\hline S & 10.67 & 8.58 \\
\hline $\mathrm{Zn}$ & 2.61 & 1.03 \\
\hline $\mathrm{Cd}$ & 26.64 & 6.11 \\
\hline Total & 100 & 99.99 \\
\hline \multicolumn{3}{|c|}{$\mathrm{c}$} \\
\hline Element & Mass $\%$ & Atomic $\%$ \\
\hline $\mathrm{O}$ & 14.49 & 37.20 \\
\hline $\mathrm{Na}$ & 9.13 & 16.31 \\
\hline S & 18.35 & 23.37 \\
\hline $\mathrm{Zn}$ & 7.10 & 4.46 \\
\hline $\mathrm{Cd}$ & 51.03 & 18.65 \\
\hline Total & 100.1 & 99.98 \\
\hline
\end{tabular}
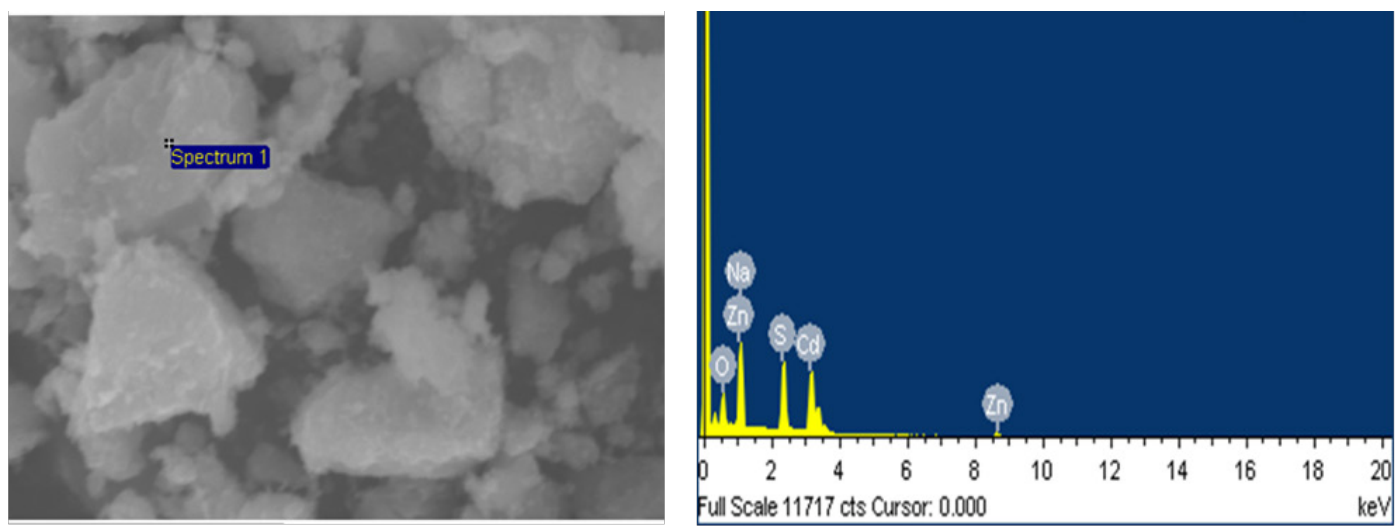

(a)
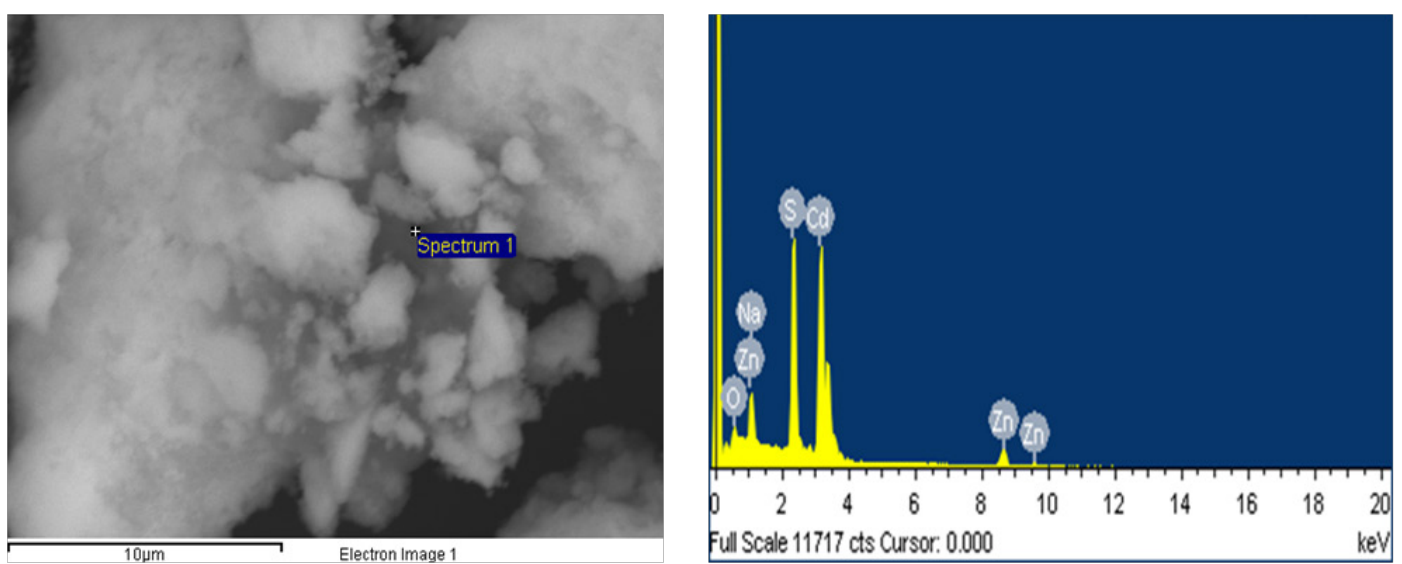

(b) 

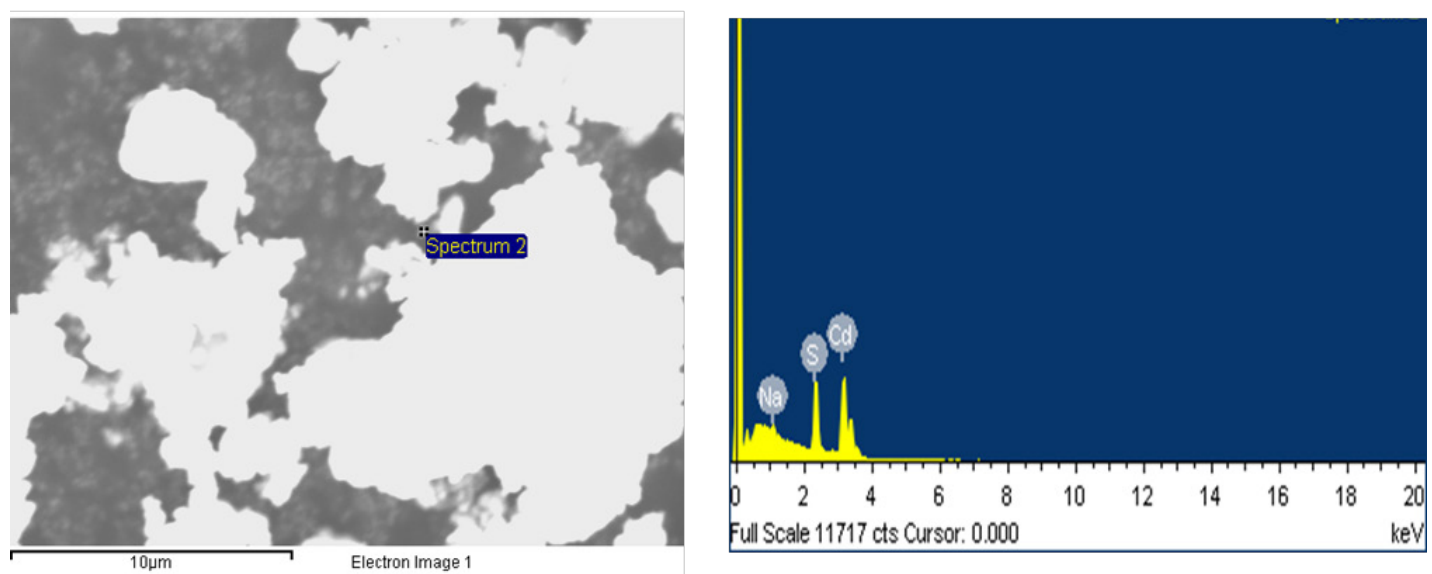

(c)

FIGURE 5. EDAX spectra of Composition of (a) CdS, (b) Zn doped CdS (0.3 M) (c) Zn

\section{ELECTRICAL CONDUCTIVITY}

Un-doped CdS and Zn- doped CdS nanocrystals were also characterized in terms of electrical conductivity. The results are presented in Table 3. By using resistance value both conductance and resistivity was determined by using digital multimeter (Keithley 2401). Conductivity and resistivity have been determined by using these formula

$$
\begin{gathered}
\varrho=\frac{R A}{L} \\
\sigma=\frac{1}{\varrho}
\end{gathered}
$$

where $\mathrm{R}$ is the Resistance $(\Omega)$; $\mathrm{L}$ is the length between two points $(\mathrm{mm})$; A is the area of nanoparticle in the form of bullet (mm); $\varrho$ is the resistivity $(\Omega)$; and $\sigma$ is the conductivity. As un-doped $\mathrm{CdS}$ has highest value of band gap and showed poor conductivity. However, it witnessed higher value of resistance. In addition, $\mathrm{Zn}$ doped CdS having dopant concentration of $0.2 \mathrm{M}$ has small band gap due to which the jumping of electron is much easier so it has relatively higher conductance (9.25E-6 $\Omega^{-1} \mathrm{~m}^{-1}$ as compare to un-doped CdS clearly shown in Figure 6). On the other hand, $0.5 \mathrm{M}$ doped nanocrystals has conductance of $7.98 \mathrm{E}-6 \Omega^{-1} \mathrm{~m}^{-1}$.

\begin{tabular}{|c|c|c|c|c|}
\hline No & Sample name & $\begin{array}{c}\text { Resistance } \\
\quad(\Omega)\end{array}$ & Resistivity $(\Omega \mathrm{m})$ & $\begin{array}{r}\text { Conductivity } \\
\left(\Omega^{-1} \mathrm{~m}-{ }^{-1}\right)\end{array}$ \\
\hline 1 & $\mathrm{CdS}$ & $6.91 \mathrm{E}-6$ & $130 \mathrm{E}-3$ & 7.69E-6 \\
\hline 2 & Zn-doped CdS (0.2 M) & $5.74 \mathrm{E}-6$ & $108 \mathrm{E}-3$ & $9.25 \mathrm{E}-6$ \\
\hline 3 & Zn-doped CdS (0.5 M) & $6.65 \mathrm{E}-6$ & $125.3 \mathrm{E}-3$ & $7.98 \mathrm{E}-6$ \\
\hline
\end{tabular}

TABLE 3. Values of resistance, resistivity, and conductivity for un-doped and 0.2 M and 0.5 M metal-doped CdS 


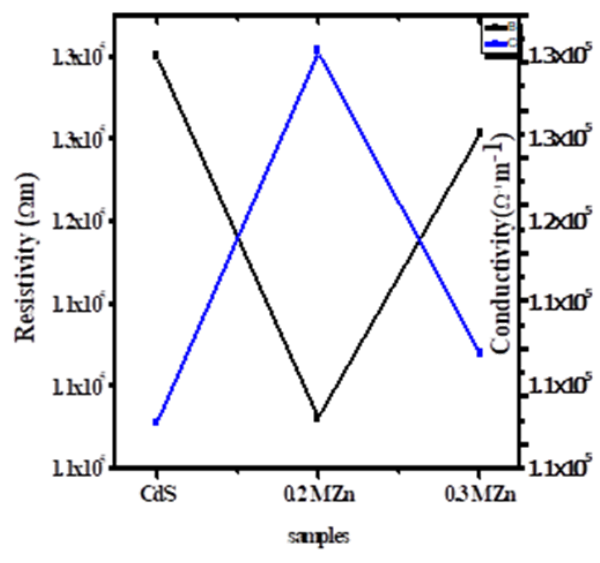

(a)

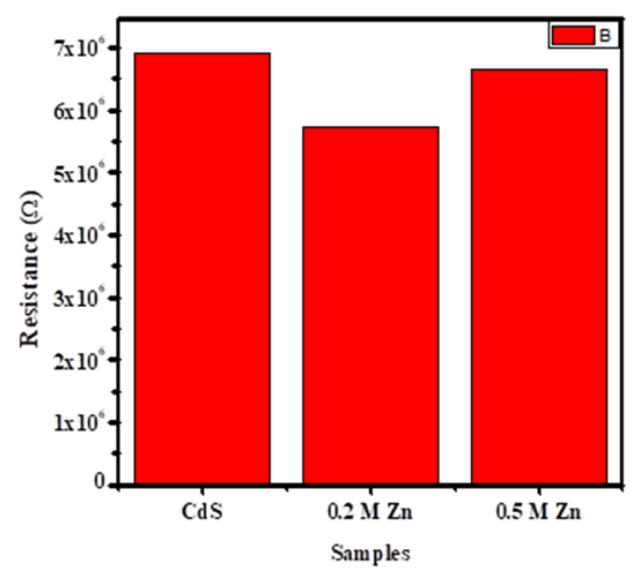

(b)

FIGURE 6. (a) Variation resistivity and conductivity of un-doped and metal-doped CdS nanoparticles and (b) Bar graph of resistance for undoped and $\mathrm{Zn}$-doped CdS nanocrystals

\section{MORPHOLOGICAL STUDIES}

SEM is a modern technique applied for the estimation of morphology and particle size. As size is in direct relation with different properties of nanocrystals and have a crucial role in is application in various fields. Through SEM, it has been determining that all the samples were in nano range including un-doped and $\mathrm{Zn}$-doped $\mathrm{CdS}$. Figure 7 shows the size of un-doped CdS has to be 52 $\mathrm{nm}$ but after the induction of $\mathrm{Zn}$ impurity size shifted to 60,53 , and $41 \mathrm{~nm}$ for $0.1,0.3$, and $0.4 \mathrm{M}$, respectively. All the synthesized nanoparticles have spherical shape. However, no other morphology like rods and wires were observed in SEM topographical images. In addition, the agglomeration of the particles noticed in the SEM micrographs due to the surfactant free process.

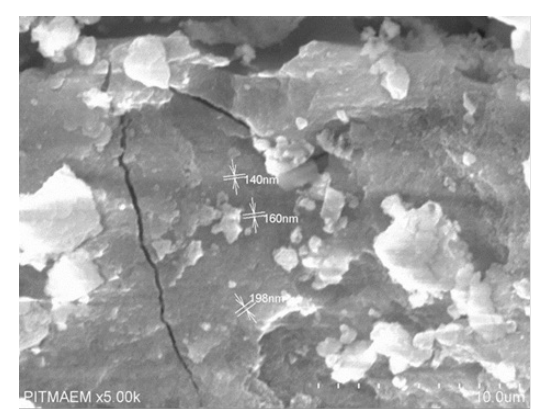

(a)

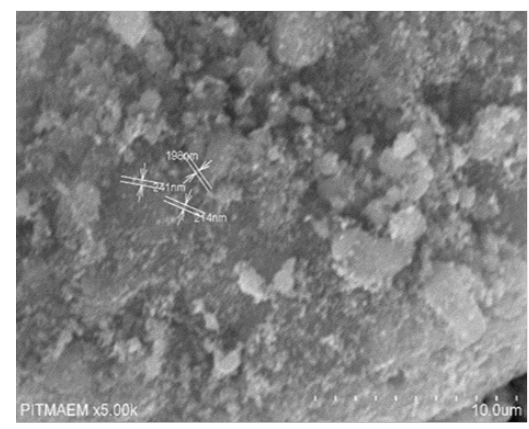

(c)

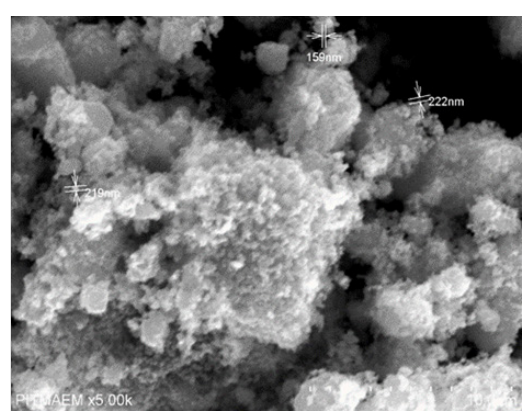

(b)

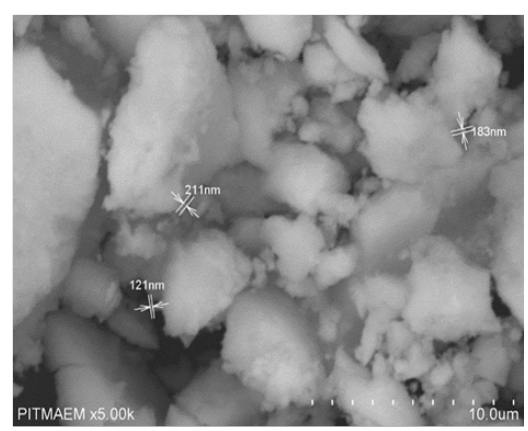

(d)

FIGURE 7. SEM images of (a) un-doped CdS, (b) $0.1 \mathrm{M}$, Zn-doped CdS,

(c) $0.3 \mathrm{M}, \mathrm{Zn}$-doped CdS, and (d) $0.5 \mathrm{M}, \mathrm{Zn}$-doped CdS 


\section{PATTERNING OF ZN-DOPED CDS BY MICROTRANSFER} MOLDING

CdS doped with $\mathrm{Zn}$ metal of $0.5 \mathrm{M}$ concentration was patterned by microtransfer molding $(\mu \mathrm{TM})$ technique. $0.5 \mathrm{M}$ Zn-doped CdS was used for molding because of higher conductivity value. The CdS solution was poured onto the molds of PDMS. Before patterning the PDMS was cleans by oxygen plasma which reduce the contact angle and convert it surface from hydrophobic to hydrophilic. The process of molding was followed by filling it with polymer and taking out the excess material by flat block. After pouring the solution on the mold, was place on the substrate and cured at $80{ }^{\circ} \mathrm{C}$ on hot plate for around 20 to $30 \mathrm{~min}$. It was let for the filling of the capillaries for $15 \mathrm{~min}$ and set for $30 \mathrm{~min}$ the folds were taken off and the pattern were left on the silicon substrate. Figure 8 shows the $\mu$ TM patterns of CdS doped with $\mathrm{Zn}$ impurity.

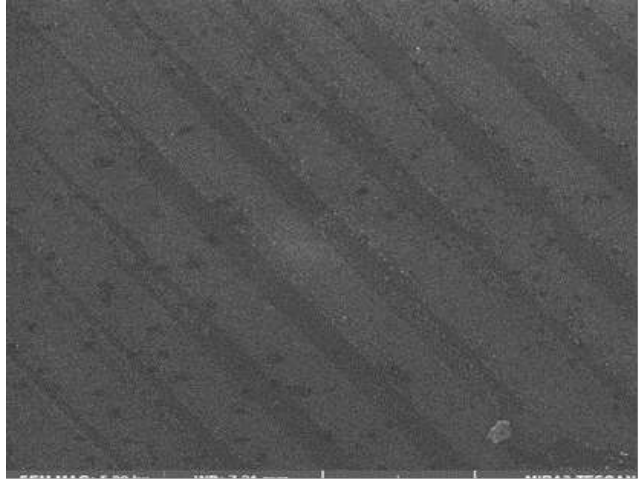

(a)

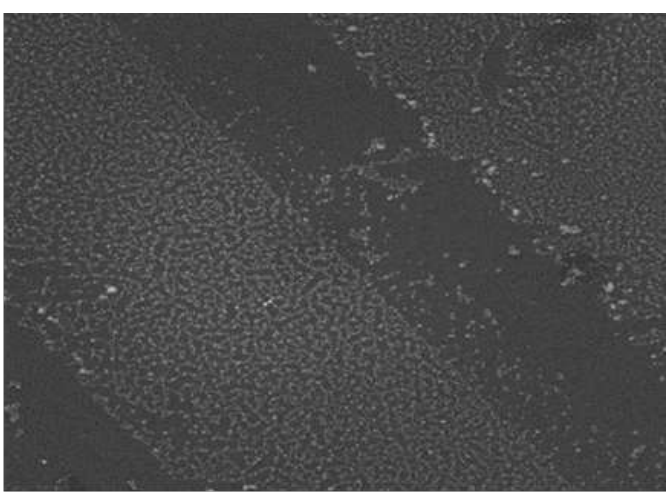

(b)

FIGURE 8 . SEM images of (a) $0.5 \mathrm{M}$ Zn-doped CdS pattern by $\mu \mathrm{TM}$ technique with low and (b) high resolution

\section{CONCLUSION}

Chemical precipitation method was followed for the synthesis of both un-doped and metal doped $\mathrm{CdS}$ nanocrystals. Optical analysis showed that the synthesized nanomaterial changes its band gap with the introduction of metal impurity in lattice of CdS. SEM micrographs showed the size to be in nano range for undoped $\mathrm{CdS}$ and $\mathrm{Zn}$-doped $\mathrm{CdS}$ where the size of CdS was $52 \mathrm{~nm}$ and after doping size changed to $60 \mathrm{~nm}$ for $0.1 \mathrm{M}$, $53 \mathrm{~nm}$ for $0.3 \mathrm{M}$, and $41 \mathrm{~nm}$ for $0.4 \mathrm{M}$. XRD was applied to determine the structure was cubic for both un-doped and metal doped CdS giving evidence of successful doping and as well as EDAX confirmed the presence of $\mathrm{Cd}, \mathrm{S}$, and $\mathrm{Zn}$ in the lattice of crystal structure. Electrical conductivity is in direct relation to the band gap as it varies with change in the band gap. $0.5 \mathrm{M}$ doped $\mathrm{Zn} \mathrm{CdS}$ has the conductance value of $7.98 \mathrm{E}-6 \Omega^{-1} \mathrm{~m}-{ }^{-1}$ and for $0.2 \mathrm{M}$ it was $9.25 \mathrm{E}-6 \Omega^{-1} \mathrm{~m}^{-1}$ but has higher conductance as compare to pure $\mathrm{CdS}$. Lithographic patterning of nanocrystals was done by $\mu \mathrm{TM}$ technique, where silicon substrate was used for better result with PDMS molds.

\section{ACKNOWLEDGEMENTS}

The authors acknowledge the financial support of SBKWU and HEC Pakistan for the present research work. Also special thanks to PCSIR, Lahore for providing the facilities to carry out this research work. We acknowledge BUITEMS for helping in some characterization techniques.

\section{REFERENCES}

Brus, L. \& Jocp, T. 1984. Electron-electron and electron-hole interactions in small semiconductor crystallites: The size dependence of the lowest excited electronic state. The Journal of Chemistry Physics 80: 4403-4409.

Erwin, S.C., Zu, L., Haftel, M.I., Efros, A.L., Kennedy, T.A. \& Norris, D.J. 2005. Doping semiconductor nanocrystals. Nature 436(7047): 91-94.

Huse, V.R., Mote, V.D. \& Dole, B.N. 2013. The crystallographic and optical studies on cobalt doped CdS nanoparticles. World Journal of Condensed Matter Physics 3(1): 46-49.

Irem, F.E. \& Boz, I. 2017. Synthesis and characterization of metal-doped ( $\mathrm{Ni}, \mathrm{Co}, \mathrm{Ce}, \mathrm{Sb}) \mathrm{CdS}$ catalysts and their use in methylene blue degradation under visible light irradiation. Modern Research in Catalysis 6(1): 1-14. 
Kane, R.S., Takayama, S., Ostuni, E., Ingber, D.E. \& Whitesides, G.M. 1999. Patterning proteins and cells using soft lithography. Biomaterials 20(23-24): 161-174.

Kazmerski, L.L. 2006. Solar photovoltaics R\&D at the tipping point: A 2005 technology overview. Journal of Electron Spectroscopy and Related Phenomena 150(2-3): 105-135.

Khan, S.U., Göbel, O.F., Blank, D.H.A. \& Elshof, J.E. 2009. Patterning lead zirconate titanate nanostructures at sub200-nm resolution by soft confocal imprint lithography and nanotransfer molding. Applied Materials \& Interfaces 1(10): 2250-2255.

Murugadoss, G. 2012. Luminescence properties of multilayer coated single structure $\mathrm{ZnS} / \mathrm{CdS} / \mathrm{ZnS}$ nanocomposites. Spectrochimica Acta Part A: Molecular and Biomolecular Spectroscopy 93: 53-57.

Jabeen, U., Shah, S.M., Hussain, N., Ali, A. \& Khan, S.U. 2016. Synthesis, characterization, band gap tuning and applications of Cd-doped $\mathrm{ZnS}$ nanoparticles in hybrid solar cells. Journal of Photochemistry and Photobiology A: Chemistry 325: 29-38.

Xia, Y. \& Whitesides, G.M. 1998. Soft lithography. Annual Review of Materials Science 28: 153-184.

$\mathrm{Wu}$, X. 2004. High-efficiency polycrystalline CdTe thin-film solar cells. Solar Energy 77(6): 803-814.

Zheng, B., Roach, L.S. \& Ismagilov, R.F. 2003. Screening of protein crystallization conditions on a microfluidic chip using nanoliter-size droplets. Journal of the American Chemical Society 125(37): 11170-11171.
Gulalai Hussain, Uzma Jabeen*, Ayesha Mushtaq, Sabeena Rizwan, Farrukh Bashir \& Farida Behlil

Faculty of Basic Sciences

SBK Women's University Quetta

87300

Pakistan

Irfan Hafeez \& M Aamir Raza

Pakistan Council of Scientific and Industrial Research Pakistan

M Najam Khan Malghani

Faculty of Engineering and Architecture

Takatu campus BUITEMS Quetta

Pakistan

Shaista Anjum

Faculty of Life Sciences

University of Balochistan

Quetta

Pakistan

*Corresponding author; email: roha64@yahoo.com

Received: 12 October 2019

Accepted: 26 March 2020 